\title{
USA and Russia in Syria and Ukraine: The Irony of Geo-Political Interventions
}

\section{Blessing Simura*}

\begin{abstract}
The battle between the USA and Russia that had been snuffed by the demise of the Soviet Union has been rekindled. The USA and Russia have regional doctrines that demarcate areas to which outside powers cannot encroach. However, the Middle East has remained a contested region for the two powers. USA has also sought to encroach into the backyard of Russia in order to contain the resurgence of the Eastern power. Both states have sought to protect their regions of influence and in the era beginning with the Arab spring, the doctrine of humanitarian intervention has been used to justify geo-political interventions. This article argues that the current tussle between the USA and Russia on Syria and Ukraine can be understood more from geopolitical struggles than from the humanitarian intervention argument
\end{abstract}

Keywords: Geo-political intervention, USA, Russia, Ukraine, Syria

${ }^{*}$ M.Sc. International Relations Student, Department of International Relations, University of Zimbabwe, Zimbabwe, simble_23@yahoo.com. 


\section{Introduction}

The defeat of Ghaddafi by the North Atlantic Treaty Organization (NATO) member states in October 2011 after Russia and China had abstained from voting in resolution 1973 opened a new chapter in the politics of uprisings and major powers' intervention. Whatever were the reasons for the Russian abstention, Moscow changed its policy when the Syrian uprising attempted to follow the Libyan script. Russia, with the alliance of China, became the protector of the Syrian government of Bashar al Assad. When the international community and the major powers had reached a stalemate in Syria as symbolized the resignation of two UN/Arab League special envoys to Syria (Kofi Annan and Lakhdar Brahimi), another uprising took place in Ukraine and led to the oust of President Victor Yanukovych. The uprising occurred because Yanukovych had refused to join the European Union and opted for more cooperation with Russia. ${ }^{1}$ The uprising therefore occurred with the blessing of the EU and the USA. It was however not approved by Russia whose man was the victim. The new power bloc that was built in Kiev was also not approved by many people in eastern Ukraine and Crimea who saw the new government in Kiev as neo-fascist who usurped power to destroy the Russian links between eastern Ukraine and Russia. Putin described the leadership in Kiev as "Neo-Nazis, Russophobes and anti-Semites," as well as the ideological heirs of Bandera, who was Hitler's accomplice during the Second World War in the Region. ${ }^{2}$ A crisis was brewed which led Crimea to secede and join the Russian Federation. Other major cities and regions in eastern Ukraine attempted to follow the Crimean script. Another standoff erupted between Russia and USA and its European allies. USA and its allies in Europe saw Russia as the major player in the Ukrainian counter-uprising. Russia was slammed with targeted sanctions and threats of more sanction and was suspended from the Group of 8 (G8).

These events are interesting in international relations. The two sides have defended their positions by attempting to stand on the high moral ground of either humanitarian intervention or protecting the governments in power from underground external power intervention. there is however a conflictual policy direction when ones notes that Russia is on the sitting government's side in Syria while on the side of the 'rebels' ${ }^{3}$ in Ukraine with the USA being on the side of the 'rebels' in Syria and the sitting government in Ukraine. This paper attempts to analyse the reasons of this irony and put forward reasons for it.

\section{A Brief overview of the Syrian and Ukrainian Crises}

There is no an exclusively accepted reasons for the uprisings in Syria (2011) and Ukraine (2013). It is important to note that the latest uprisings and wars in these countries are not new. They are the latest in a number of upheavals that have engulfed the countries in their years of existence. Syria had, before the 2011 uprisings experienced a latest civil war in the early 1980s, which was only put down by a brutal crackdown by Hafez al Assad. Ukraine had its latest upheaval before the current one in 2004 in the name of the Orange Revolution.

\section{Syria}

The uprising in Syria started as peaceful demonstrations against some undemocratic practices by the Assad government. ${ }^{4}$ However, the demonstrations, due to a government crackdown and interference by militant forces, took a sectarian line pitting the minority but dominant Alawites against the majority Sunni Muslims. ${ }^{5}$ The 'rebels' were emboldened by the successes by the uprisings in Tunisia, Egypt and Libya.

In relation to the regional examples, the Syria rebels tried to push for a repetition of Libya. The SNC was quickly formed in the manner in which the NTC was formed in Libya. The leaders of 
the council/coalition got recognition from the EU, USA and GCC states and other regional states. ${ }^{6}$ The SNC was pro-western and pro-Sunni. They got military and financial assistance from the West and Sunni States in the gulf ${ }^{7}$ as well as sanctuary from Turkey, a pro-western state and a member of NATO.

On the other hand, the Assad government labeled the uprising as a western instigation. The Assad government also argued that the uprising was being fought by terrorists and that USA and other Western states were funding terrorists to topple it (the government). ${ }^{8}$ This argued was accepted by Russia, China and also Iran. Russia and its allies on the Syrian case argued that the west was pushing for regime change in states they had no cordial relations with the governments. This was seen as a means to extend USA and NATO influence in resource rich and important geo-political zones. From this argument Libya fell because the west wanted to control its rich petroleum wealth while Syria is seen as the last bastion in the west's battle against Iran. ${ }^{9}$ Russia therefore defended Syria at the Security Council and remained a major weapons supplier during the crisis.

\section{Ukraine}

Ukraine has been a major part of the Russian empire. Historically, Ukraine could not be separated from Russia. While the fall of the Soviet Union in the early 1990s saw Ukraine being geographically separated from Russia, Russia consider it an important part of its sphere of influence. Since its creation, Ukraine had been torn between joining the European Union and in extension NATO, or remaining a Russian partner state and joining the Eurasian customs union which is dominated by Russia. The tipping point came in November 2013 when then president, Victor Yanukovych decided not to sign an Association Agreement and a deep and comprehensive Free Trade Area agreement with the EU and opted for a deeper cooperation with Russia. ${ }^{10}$ Pro-western demonstrations began in Kiev calling on the abandonment of the Russian deal and join the EU. The demonstrations continued into December and turned bloody. A compromise agreement which was mediated by the foreign ministers of France, Germany, and Poland failed to materialize.

On 22 February 2014 president Yanukovych disappeared from Kiev as protesters occupied state buildings. The Ukrainian parliament responded by stripping the president of his powers and a new government was formed. ${ }^{11}$ Pro-western leaders, interim president Olexander Turchynov and Prime Minister Arsebiy Yatseniuk, took over power and aligned Ukraine to the West.

After the ascension of the new government, the semi-autonomous region of Crimea, which is home to more than 60 percent ethnic Russian quickly held a referendum on 16 March 2014 to break away from Ukraine and join the Russian Federation. The Russian government accepted to annex Crimea, while western states viewed is as a breach of Ukrainian sovereignty and a threat to the international order. A backlash of the uprising started against the new government in Kiev from the eastern cities that are predominantly ethnic Russia. Emboldened by the Crimean case, the regions of Donetsk and Luhansk pushed on for secession and to join Russia.

While Russia denied the calls to annex the other Ukrainian territories, and stand by Putin's words that, "We do not want to divide Ukraine, we do not need that" 12 , when he accepted Crimea into the Russian federation, Russian forces conducted military drills in the border towns that were seen as military threats to Ukraine or a move to embolden the rising masses in the eastern regions.

The USA and the EU blamed Russia for the escalation in eastern Ukraine. NATO secretary general, Anders Fogh Rasmussen echoed the same sentiments and called on Russia to deescalate the crisis. ${ }^{13}$ Russia denied having a hand in the crisis. However, the appearance of gunmen in unmarked military uniforms identical to the one used by Russian forces and the discipline they exhibited ${ }^{14}$ led the west to argue that Russia was behind the uprising or had sent in its special forces to act as proRussian Ukrainians. The crisis deepened with military exchanges between the secessionists and the 
Kiev government even after the presidential elections in May 2014 which were won by Petro Poroshenko.

While Russia has denied any wrong doing in the Ukrainian backlash, it has shown support for the deposed president, Yanukovych, contempt of the interim government after the uprising and resentment of the newly elected government. While it has accepted to have talks and spoke against secession of eastern Ukraine, it has argued that it has no control of the movements. This has not helped the crisis which has also seen the former bipolar power in a new stand-off reminiscent of the Cold War era.

\section{Clash of Regional Control Doctrines}

In 1823 James Monroe declared that countries in the American continents where not to be considered colonies of the warring European states and that any interference by the European states in the affairs of the American continents was considered as endangering the peace and security of the continents. ${ }^{15}$ The declaration effectively stopped the European states from interfering in affairs across the Atlantic. The doctrine was not meant to liberate South America from colonialism but USA declaration of control and politics within its vicinity. The Monroe Doctrine was the most influential regional doctrine that has influenced major powers to try and curve their exclusive spheres of influence and control that are regarded as regions of national interest.

In January 1980, the Carter Doctrine added the Middle East as strategic region which an attempt by any outside force to gain control of would be regarded as an assault on the vital interests of the United States of America, which would be repelled by any means necessary, including military force. ${ }^{16}$ The region is so important that the USA is willing and compelled to sacrifice its military personnel and assets to safeguard. The doctrine was promulgated inorder to deter the then Soviet Union from encroaching into the Middle East and Persian Gulf regions after the Soviet Union had invaded Afghanistan in 1979.

Equally, even after the fall of the Soviet Union, Russia has its own regional control doctrine. Russia has always taken active and passive actions to guards the Caucasus region and the former soviet countries from external interference specifically interference from the USA. Any encroachment into this region is regarded as a threat to Russian national interest and security.

USA has been an offensive actor in Middle East relations. The importance of the region to USA is hinged not only on the need to keep the petroleum tapes running to USA and its allies and curbing terrorism but also to the need to control the petrodollar system ${ }^{17}$ and the existence of Israel. It is for this reason that Jimmy Carter declared that the "An attempt by any outside force to gain control of the Persian Gulf (Middle East) region will be regarded as an assault on the vital interests of the United States of America, and such an assault will be repelled by any means necessary, including military force" ${ }^{\prime 18}$ Because of this declaration, USA Middle East policy is continuously reviewed and threats redefined. This is exemplified by Saddam Hussein who at one time is seen as a USA ally and later turns into a foe and invaded in 2003.

The constant transformation of USA's Middle East policy is the reason why Syria, which was not much seen as a special interest state, becomes important soon after the fall of Saddam Hussein's Iraq. Syria grew to be a state of importance arguably because as a state under Alawite (a Shiite sect) it was the last major ally of Iran, which the then USA President George Bush classified among the "axis of evil"19 states together Iraq and North Korea. Being under the control of Alawites meant that Syria, like Iran, was viewed as a threat by the dominant Sunni states like Saudi Arabia, Qatar, Kuwait and United Arab Emirates, in the region who are all USA allies. 
Another reason for the need to change the leadership in Syria was driven by Israel's security concerns. Syria provided safe external base for Hamas, a Palestinian liberation movement, a relationship which is now strained after the Syria uprising by predominantly Sunni groups. ${ }^{20}$ It supported and also used as a transit route for Iranian financial and military assistance to Hamas and Hezbollah, an anti-Israel Shia militia group based in Lebanon to counter Israel dominance in the region. ${ }^{21}$ John Mearsheimer and Stephen Walt argue that, there is a USA / Israeli plan to effect regime change against governments in the Middle East that are not friendly to them. They further add that the chief targets are Iran and Syria, and Iraq before the overthrow of Saddam Hussein. ${ }^{22}$ They further note that the Israeli lobby in the USA was clear that "there has got to be regime change in Syria." 23

It can be argued that because of the plethora of reasons noted, the uprising against Assad in 2011 was given support by the USA and her European and Middle East allies. The rebellion was contextualized as pro-democracy uprising and deserved military support or a humanitarian intervention in the style of the intervention in Libya. ${ }^{24}$ However, the paradox of this support could be seen in the blind eye the USA turned on the Arab Spring style uprising in Bahrain which the government crushed with Saudi Arabian led GCC military support. ${ }^{25}$ This paradox is clearly proven by the fact that when the Syrians rose for different reasons and with different tones ${ }^{26}$, the USA called on Bashar al Assad to step down and allow for democratic processes, ${ }^{27}$ but in the uprising in Bahrain and the Saudi Arabia led intervention, the USA called on the leadership to exercise restraint. ${ }^{28}$

At the United Nations (UN) level the USA and its allies sponsored Security Council resolutions that sought to pave way for an international military intervention and/or empower the Syrian opposition in a manner resolution 1973 paved way for the military intervention and support for Libyan National Transitional Council (NTC).

Outside the UN, USA gave the SNC financial support. It also supported the different militia groups that were not classified as terrorist or working with terrorist, with military support. ${ }^{29}$ The media from the USA followed the national policy and broadcasted in a manner that was supportive of the Syrian opposition. ${ }^{30}$

The machinations by the USA can be understood in light of the Carter doctrine which exclusively classified the Middle East as strategic region of vital national interest to the USA. ${ }^{31}$ The intervention in Syria was a war by proxy in a greater Middle East policy that targeted Iran. It would also translate that the Middle East would be a region under the rule of USA allies and countries that do not threaten the security of Israel. It can also be seen as a war that was aimed at pushing out the least Russian influence in the region. Syria has major arms deals with Russia and the Syrian port of Tartus houses a Russian Naval military facility, the only one outside the vicinities of Russian.

The argument that the USA has a policy to export democracy sound hollow given the fact that it has maintained cordial relations with the monarchies and military dictators in either the name of fighting terrorism as in the case of Yemen under Saleh or for the security of Israel as was the case with Egypt. The USA denied classifying the ouster of Mohamed Morsi by the Egyptian army on 3 July 2013 as a coup due to the need to preserve the Middle East peace treaty for Israel, and air space and naval privileges the USA enjoys from $\mathrm{Cairo}^{32}$, a declaration which would have forced the USA to review its military aid and cooperation with Cairo.

Russia, on the other hand argued that it could not support or allow for the passage of any Security Council resolution on Syria after NATO abused resolution 1973 which was deficient in that it gave room for interference in the internal affairs of a sovereign state in a manner that was reminiscent of the mediaeval crusades. ${ }^{33}$ True as it is, Russia knew that the interpretation of Security Council resolutions can be different in implementation from that given during the debating period. Russia had learnt from the Kosovo example that a Security Council resolution that was not watertight could be abused for self interest by the intervening state. The argument that Russia did not allow the passage of any resolution on Syria due to the Libyan experience is therefore questionable. 
Strategic reason should be seen as providing a better understanding to the Russian behaviour in relation to the Syrian case. Russia could have allowed the passage of resolution 1973 because Muammar Ghaddafi had, in his later stages of his rule, drifted to the western hemisphere and redirected his foreign policy to placate western powers. This is evidenced by Libya's acceptance of the responsibility of Lockerbie bombing, and oil and other business agreements and investments with and/or in Europe and the USA companies.

However, the Syrian case, in Russia regions of national interest is different from that of Libya. While Libya had 'dumped' its traditional allies in its re-engagement overdrive with the west, Syria remained a Russian ally since the days of Hafez al Assad. Even when Syria cooperated with the USA in fighting Al Qaeda, it did not do so at the expense of its relationship with Russia. Syria is also a strengthening ally of Iran against the Shia-Sunni regional battle. Iran being a Russian ally in the Middle East could not be allowed to begin the process of falling through the fall of Syria. Russia, therefore, used its veto powers in the Security Council on Syria more than it had done on any other country to maintain equilibrium in Middle East so as to balance its influence against that of Russia.

Ukraine is an extension of the battle of the control of strategic regions between USA and Russia. Deducing from its actions, Russia had already demarcated the Caucasus region and the Eurasian territories as its inviolable sphere of influence. Russia has not been comfortable with the 'colour revolutions' in Georgia (Rose Revolution, 2003), Ukraine (Orange Revolution, 2004) and Kyrgyzstan (2005) which it viewed as western instigations to reduce the Russia sphere of influence which it views as pretexts to bring NATO to its backyard. ${ }^{34}$ The Georgian crisis of 2008 ended with Russia fighting a war against Georgia and supporting the autonomy of Abkhazia and South Ossetia, a recognition which is not shared by other states in the international community, specifically the USA and the EU states.

Russia has not been comfortable with the NATO encroachment into its sphere of influence. Putin summarized the Russian regional policy against the encroachment NATO when he stated that, "NATO remains a military alliance and we are against having a military alliance making itself at home right in our backyard or in our historic territory." ${ }^{35}$ Ukraine is strategically important that Russia cannot leave it to fall to USA influence. Its geographical location makes it the bridge between Europe and Russia, and with it Russia is geopolitically safe from European and American threats.

Ukraine, before the break away of Crimea was house to the Russian Black Sea fleet. Even though it had been neglected for some years due to the non-conclusive agreement on its future in Sevastopol, the Black Sea fleet is important for Russian naval access to the Mediterranean and Southern Europe. While Yanukovych had renegotiated the Ukrainian naval lease agreement from 2017 to 2042, the agreement was not guaranteed in the future pro-European government in Kiev. One would also wonder if Ukraine would have joined NATO if it would have allowed for the stay of a Russian fleet in its territory.

Geographically, the Ukrainian border with Russia is a few hundred miles from Moscow, the Russia capital city. If Ukraine is to join the EU and subsequently NATO, it would be bringing a Russian enemy on its door step and within closer striking distance of Moscow. Putin also stated the Russian fears if Ukraine with Crimea was to join the NATO alliance that, "Let me note too that we have already heard declarations from Kiev about Ukraine soon joining NATO. What would this have meant for Crimea and Sevastopol? It would have meant that NATO's navy would be right there in this city of Russia's military glory and this would create not an illusory but a perfectly real threat to the world of southern Russia." 36

The Russian concerns for shutting out the USA from Eastern Europe can be seen as the reasons why the USA has been pushing to draw closer. Since Putin came to power, there has been growing concerns in the USA with regards to his desires to push Russian international influence. ${ }^{37}$ The USA has been in the drive to contain the growing Russian influence, while Russia has been 
pushing to 'claim its place on the moon'. It is because of this reason that there has been an escalation in the geo-political struggle between Russia and USA.

Be that as it may, the international order of the pre UN era and the Cold War era has been surpassed by international developments. The transformations in the international system now mean that states can no longer simply invade other states without a legal justification. In the absence of a viable justification, powerful states have adopted the responsibility to protect, formerly known as humanitarian intervention, to pursue geopolitical interest. It is this justification that the USA and its allies have used to try to gain access legally to Syria through a Security Council resolution. The irony is found in the fact that while the USA was sponsoring Security Council resolutions on Syria, it was also simultaneously funding the rebels, which is against the concept of humanitarian intervention. Russia also argued that its intervention in Ukraine was a humanitarian intervention. ${ }^{38}$ The justification raises questions on the reasons for military intervention for humanitarian purposes. There was no massacre of any target group in Ukraine and hence Russia also tried to strengthen its argument by saying that it had been invited to intervene by the then Ukrainian president, Viktor Yanukovych. ${ }^{39}$

\section{Conclusion}

The crises in Syria and Ukraine call for a revisit on the concept of military intervention for humanitarian purposes. The crises have shown that while the concept is a noble one, the international community should pay heed to Ian Brownlie's (cited in Ramsbotham and Woodhouse) argument that it can be abused by vigilantes and ambitious power to extend their spheres of influence. ${ }^{40}$ The Syrian crisis is a noble case which would meet most of the requirements for a military intervention to save the suffering masses. However, the case will go down in history books as another failed case due to the primacy of the interest of the powerful regional and international players. On one hand, the USA and its allies financed and armed the rebels and also called for a military intervention to assist the same rebels. Such an approach is hypocritical and against the moral standards for an intervention. Russia and its allies on the other hand continued to arm and defend the Syria government in the Security Council. All the calculations were at the expense of the suffering civilians. The Syrian crisis shows that USA and Russia as the leading powers intervened in the conflict not because of the need to fulfill a moral responsibility to protect the civilians but with hidden interest to pursue geo-political influence.

This paper argued that the Ukrainian crisis is an extension of the Syrian geo-political tussle between the USA and Russia. While Russia has tried in part to justify its intervention as a humanitarian adventure and in part an intervention by the legitimate president of Ukraine. This paper did not seek to discuss the second claim. However, the first claim has no basis if weighed against the principles of military intervention for humanitarian purposes. There was no threat on the lives of the civilians by the interim Ukrainian government after the fall of Yanukovych. The Russian intervention can therefore be explained in terms of its geo-political interest.

USA's intervention can also be seen in the light of geo-political interests. USA had tussled with Russia regarding the Ukrainian fate since the birth of Ukraine. Having access to Ukraine is a major blow on Russian prestige and influence in global politics. Hence the USA had always had preferred candidates in Ukrainian elections with the latest official telephone links between US officials in Kiev and Washington showing that there had been preferred and non-preferred candidates to take over in Kiev. ${ }^{41}$

The two crises have shown that great powers can be so desperate to use any case at their disposal to justify their actions if there is a major gain or major threat on their interest. The Middle East and Eastern Europe are regions of strategic importance to both the USA and Russia. It is for this 
reason that the Syria crisis ended with a stalemate while the backlash in the Ukrainian uprising have turned into a 'war zone'.

\section{Notes}

${ }^{1}$ Ben Smith and Daniel Harari, "Ukraine, Crimea and Russia," House of Commons Library, Research Paper 14/16, 17 March 2014, p. 1

${ }^{2}$ Vladimir Putin, President of the Russian Federation's address to the State Duma Deputies, Federation Council Members, Heads of Russian regions and Civil society Representatives in the Kremlin on the Annexation of Crimea, 18 March 2014, accessed 24 June 2014, www.eng.kremlin.ru/news/6889

${ }^{3}$ This may be a contested term. Here, it is used in reference to those who rise in armed resistance against an established ruler and/or government.

${ }^{4}$ Angela Joya, "Syria and the Arab Spring: The Evolution of the Conflict and the Role of the Domestic and External Factors," Ortadogu Etutleri, Vol 4, No. 1, July 2012, p. 27, 31-32

${ }^{5}$ Fredric C. Hof and Alex Simon, "Sectarian Violence in Syria's Civil War: Causes, Consequences and Recommendations for Mitigation," paper commissioned by the Center for the Prevention of Genocide, United States Holocaust Museum, accessed 23 April 2013, www.ushmm.org/genocide/pdf/syria-report.pdf, p 1

${ }^{6}$ Stefan Talmon, "Recognition of Opposition Groups as the Legitimate Representative of a People," Chinese Journal of International Law, 31 May 2013, par. 1-5, see also Christopher M. Blanchard, "Libya: Transition and US Policy," Congressional Research Service (CRS) Report for Congress, 25 October 2014, www.crs.gov, p. 17

Angela Joya, "Syria and the Arab Spring: The Evolution of the Conflict and the Role of the Domestic and External Factors," p. 35

${ }^{8}$ Fredric C. Hof and Alex Simon, "Sectarian Violence in Syria's Civil War: Causes, Consequences and Recommendations for Mitigation," p. ii \& 2

9 Angela Joya, "Syria and the Arab Spring: The Evolution of the Conflict and the Role of the Domestic and External Factors," p. 35; see also, Seymour M. Hersh, "Annals of National Security: The Redirection," The New Yorker, 5 5 March 2007, accessed 25 June www.m.newyorker.com/reporting/2007/03/05/070305fa_fact_hersh?currentPage=all

${ }^{10}$ Ben Smith and Daniel Harari, "Ukraine, Crimea and Russia," p. 1

11 "Ukrainian Parliament Votes to Strip Yanukovich of Powers as President Leaves Kiev," Russia Today, 22 February 2014, accessed 26 June 2014, www.rt.com/news/ukraine-president-parliament-chaos-249/

12 Vladimir Putin, President of the Russian Federation's address to the State Duma Deputies, Federation Council Members, Heads of Russian regions and Civil society Representatives in the Kremlin on the Annexation of Crimea, 18 March 2014, accessed 24 June 2014, www.eng.kremlin.ru/news/6889

13 "NATO Secretary General Says Ukraine Crisis Amplifies Need to Boost Defence Cooperation," accessed 25 June 2014, www.nato.int/cps/en/natolive/news_109187.htm

${ }^{14}$ Danielle Wiener-Bronner, "Ukraine's Pro-Russia 'Militia' Look Suspiciously Like Veteran Soldiers," The Wire, 21 April 2014, accessed 1 July 2014, www.thewire.com/global/2014/04/ukraine-soldiers-russia/360969/

15 "The Monroe Doctrine", accessed 28 May, 2012: www.utahlinks.org/learn/docs/Monroe.pdf

${ }^{16}$ President Jimmy Carter quoted in Bob Woodward; The Commanders; New York; Simon and Schuster; 1991; p. 230

${ }^{17}$ Blessing Simura, An Analysis of the Role of Oil in Shaping the USA Foreign Policy in the Middle East: The Case of the American-led Invasion of Iraq in 2003; Unpublished Master of Science Dissertation in International Relations; University of Zimbabwe; April 2011; 17-21

${ }^{18}$ President Jimmy Carter quoted in Bob Woodward; The Commanders; p.20

19 George W. Bush, "2002 State of the Union Address," accessed 25 June 2014, www.cnn.com/2002/ALLPOLITICS/01/29/bush.speech.txt/

${ }^{20}$ Karin Laub and Brian Murphy, "Hamas Drifting from Longtime Patron Iran," The Seattle Times, 9 February 2012, accessed 25 June 2014, www.seattletimes.com/html/nationworld/2017465373 apmlshiftinghamas.html

${ }^{21}$ Casey L. Addis and Christopher M. Blanchard, "Hezbollah: Background and Issues for Congress," Congressional Research Service (CRS) Report for Congress, 3 January 2011, www.crs.gov, p. 17-19 
${ }^{22}$ John J. Mearsheimer and Stephen M. Walt, "The Israel Lobby and US Foreign Policy," John F. Kennedy School of Government (Harvard University), Faculty Research Working Paper Series (RWP 06-011), March 2006 , p. $25 \& 29$

${ }^{23}$ John J. Mearsheimer and Stephen M. Walt, "The Israel Lobby and US Foreign Policy," p.36

${ }^{24}$ Angela Joya, "Syria and the Arab Spring: The Evolution of the Conflict and the Role of the Domestic and External Factors," p. 35

${ }^{25}$ Kenneth Katzman, "Bahrain: Reform, Security, and US Policy," Congressional Research Services (CRS) Report to Congress, 29 June 2012, accessed 23 December 2012, www.crs.gov, p. 8

${ }^{26}$ Angela Joya, "Syria and the Arab Spring: The Evolution of the Conflict and the Role of the Domestic and External Factors," p. 31-35

${ }^{27}$ CNN Wire Staff, "US, Europe Call for Syrian Leader al Assad to Step Down," CNN, 19 August 2011, accessed26 June 2014, www.cnn.com/2011/POLITICS/08/18/us.syria/

${ }^{28}$ Kenneth Katzman, "Bahrain: Reform, Security, and US Policy," 15

${ }^{29}$ Angela Joya, "Syria and the Arab Spring: The Evolution of the Conflict and the Role of the Domestic and External Factors," p. 35 \& 36

${ }^{30}$ Angela Joya, "Syria and the Arab Spring: The Evolution of the Conflict and the Role of the Domestic and External Factors," p. 27

${ }^{31}$ Bob Woodward; The Commanders; p. 20

${ }^{32}$ Kim Ghattas, "US Credibility 'in tatters' Over Egypt Crisis," BBC News, 16 August 2013, accessed 25 June 2014, www.bbc.com/news/world-middle-east-23721918

${ }^{33}$ Global Research, "Putin Likens UN Security Council Resolution on Libya to a Medieval Crusade," 21 March 2011, accessed 30 September 2013, http://www.globalresearch.ca/putin-likens-un-security-council-resolutionon-libya-to-a-medieval-crusade

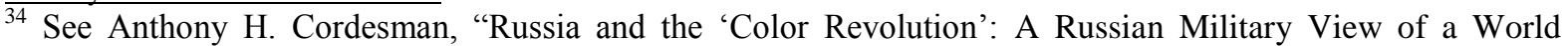
Destabilized by the US and the West (Key Briefs)," Center for Strategic and International Studies (CSIS), 28 May 2014

35 Vladimir Putin, President of the Russian Federation's address to the State Duma Deputies, Federation Council Members, Heads of Russian regions and Civil society Representatives in the Kremlin on the Annexation of Crimea, 18 March 2014, accessed 24 June 2014, www.eng.kremlin.ru/news/6889

${ }^{36}$ Vladimir Putin, President of the Russian Federation's address to the State Duma Deputies, Federation Council Members, Heads of Russian regions and Civil society Representatives in the Kremlin on the Annexation of Crimea, 18 March 2014, accessed 24 June 2014, www.eng.kremlin.ru/news/6889

${ }^{37}$ Jim Nichol, "Russian Political, Economic, and Security Issues and US Interests," Congressional Research Service (CRS) Report for Members and Committees of Congress, 31 March 2014, www.crs.gov, p. 38

${ }^{38}$ Ben Smith and Daniel Harari, "Ukraine, Crimea and Russia," p. 21

${ }^{39}$ Edith M. Lederer and Peter James Spielmann, "Russia Says Yanukovych Requested Troops in Crimea," The Seattle Times, 3 March 2014, accessed 1 July 2014, www.seattletimes.com/html/nationworld/2023040147apxunukraine.html

${ }_{40}$ Oliver Ramsbotham and T. Woodhouse, Humanitarian Intervention in Contemporary Conflict: A Reconceptualization, Polity Press, Cambridge, 1996, p. 64

${ }^{41}$ Ben Smith and Daniel Harari, "Ukraine, Crimea and Russia," p. 25 